\section{A patient with protein-losing colon cancer with massive ascites who was successfully treated by surgical resection of the tumor}

The amount of protein leakage from colon cancers is thought to be less than occurs with other colon diseases [1], and cases of protein-losing colon cancer have rarely been reported. We encountered a case of protein-losing colon cancer associated with severe diarrhea and hypoproteinemia in an 85-year-old woman. Computed tomography showed a large tumor in the ascending colon and massive ascites (Figure $\mathbf{1}$ ). Total colonoscopy revealed a giant nodular tumor with a surface that was whitish-yellow in color in the ascending colon (Figure 2). The patient was apparently not considered suitable for surgery because of carcinomatosa, but abdominal paracentesis was not suggestive of malignancy. We suspected that the hypoproteinemia was caused by protein leakage from the colonic lesion. The fecal alpha ${ }_{1}-$ antitrypsin clearance was measured and found to be remarkably high at $232 \mathrm{ml} /$ day (normal ramge $<20 \mathrm{ml} /$ day). Human serum albumin scintigraphy revealed marked albumin leakage from the lesion (Figure 3).

A right hemicolectomy was performed and the pathological diagnosis was poorly differentiated adenocarcinoma with marked dilatation of the lymphatic ducts (Figure 4). It has been suggested that the pressure on the lymphatic ducts on the tumor surface is raised in such cases, leading to loss of protein [2]. After the peration, the patient's alpha ${ }_{1}$-antitrypsin clearance returned to normal levels and human serum albumin scintigraphy did not demonstrate any sites of albumin loss. Her diarrhea and ascites resolved (see Figure $\mathbf{5}$ ) and her condition improved dramatically, and at follow-up at 14 months she was in good health.

Alpha ${ }_{1}$-antitrypsin clearance $[1,3,4]$ and human serum albumin scintigraphy [5] proved very useful for establishing the diagnosis of protein-losing colon cancer in this case, and these investigations were a turning point in the diagnosis of protein leakage from the cancer. There could be a few treatable cases of protein-losing co-

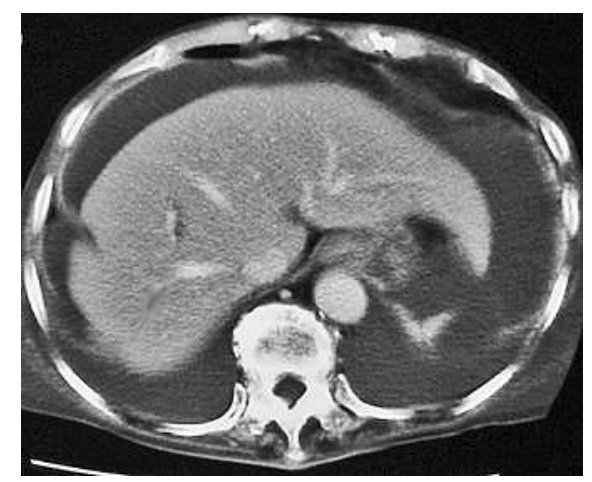

Figure 1 Computed tomography on admission showed massive ascites, similar to that seen in carcinomatosa.

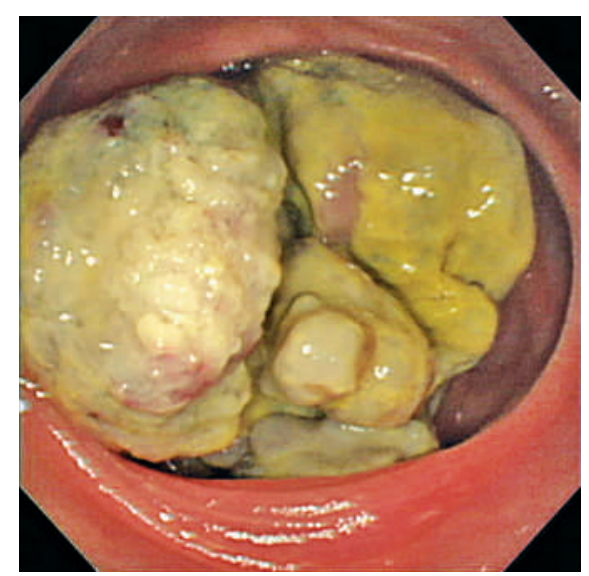

Figure 2 Total colonoscopy revealed a giant, cauliflower-like nodular tumor, with a surface that was whitish-yellow in color in the ascending colon.

lon cancer among the many patients with colon cancer and ascites. Once the diagnosis of protein-losing colon cancer is established, resection of the tumor should lead to clinical improvement, so it is important to suspect protein-losing colon cancer and to diagnose these tumors appropriately.

Endoscopy_UCTN_Code_CCL_1AD_2AB

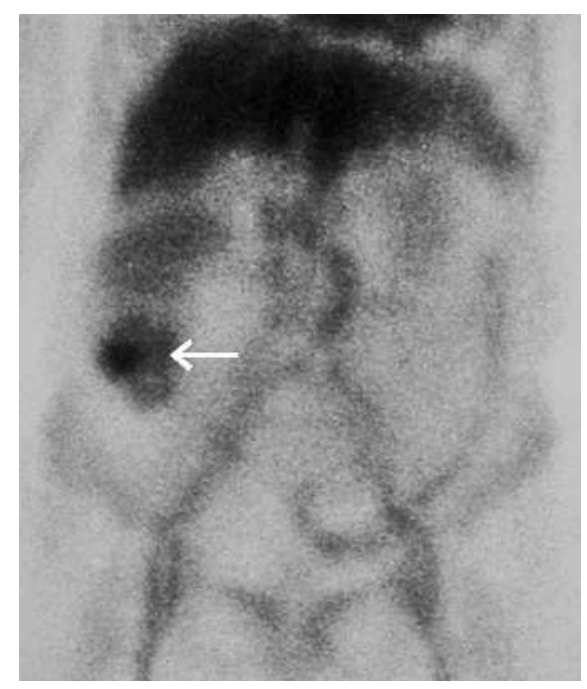

Figure 3 Human serum albumin scintigraphy showed marked albumin leakage from the ascending colon (arrow).

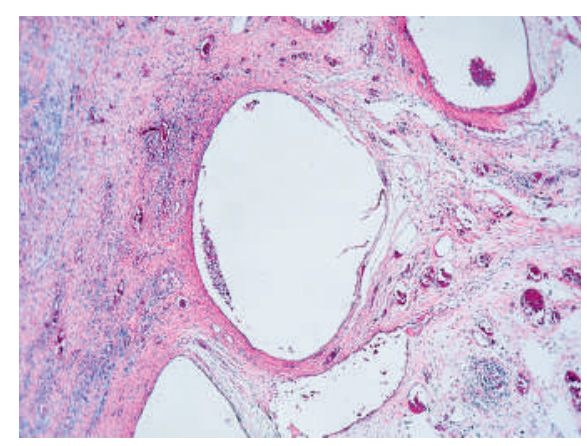

Figure 4 Histopathological examination showed marked dilatation of the lymphatic ducts within the lesion (hematoxylin and eosin stain, $\times 40$ magnification).

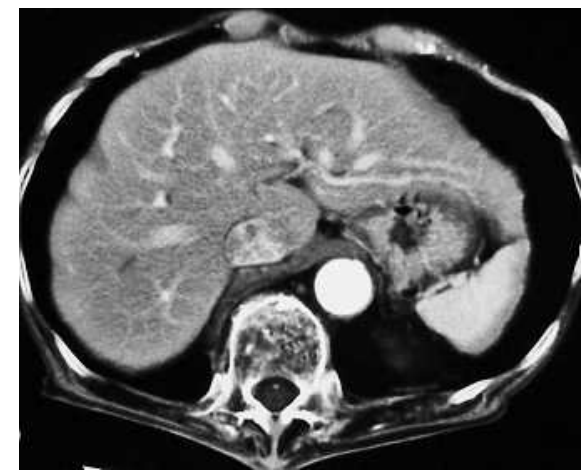

Figure 5 Computed tomography 4 months after the operation showed that the ascites had disappeared. 


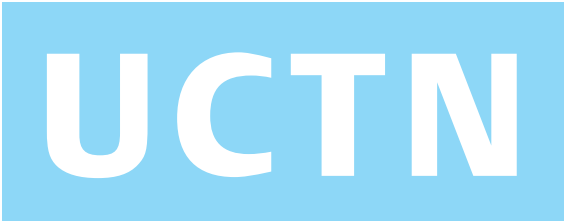

Y. Nomura, M. Abe, K. Miyawaki, D. Kenemitsu, K. Tomikashi

Digestive Disease Center,

Kohoku General Hospital, Kinomoto,

Japan.

\section{References}

${ }^{1}$ Saitoh O, Matsumoto $\mathrm{H}$, Sugimori $\mathrm{K}$ et al. Intestinal protein loss and bleeding assessed by fecal hemoglobin, transferrin, albumin, and alpha-1-antitrypsin levels in patients with colorectal diseases. Digestion 1995; 56: $67-75$
2 Mangla JC, Taylor E, Cristo C. Primary duodenal carcinoma with protein-losing enteropathy. Am J Gastroenterol 1977; 67: 73 - 76

${ }^{3}$ Bernier JJ, Florent C, Desmazures C et al. Diagnosis of protein-losing enteropathy by gastrointestinal clearance of alpha 1-antitrypsin. Lancet 1978; 7: $763-764$

${ }^{4}$ Florent C, L'Hirondel C, Desmazures C et al. Intestinal clearance of alpha 1-antitrypsin: a sensitive method for the detection of protein-losing enteropathy. Gastroenterology 1981; 81: $777-780$

5 Chiu NT, Lee BF, Hwang SJ et al. Protein-losing enteropathy: diagnosis with (99m)Tc-labeled human serum albumin scintigraphy. Radiology 2001; 219: 86-90
Corresponding Author

M. Abe, M.D.

Digestive Disease Center Kohoku General Hospital 1221 Kuroda Kinomoto

Ika

Shiga

Japan

Fax: $\quad+81-749-82-4877$

E-mail: mabe828@ybb.ne.jp 